\title{
KAJIAN KUALITAS PEMBAKARAN TERHADAP PENGGUNAAN FILTER BBM PADA MESIN DIESEL
}

\author{
Tatun H Nufus ${ }^{1}$, Ariek Sulistyowati, Asep Yana Y, Fitri Wijayanti \\ Teknik Mesin, Politeknik Negeri Jakarta, \\ Jalan Prof. Dr. G. A. Siwabessy, Kampus UI, Depok 16425 \\ e-mail: 1thnufus@gmail.com
}

\begin{abstract}
The price of oil fuel continues to rise, decreased supplies oil at the other side, those two factors motivate researchers to conduct research related to the efficient use of fuel. Have been made three types of fuel oil which the principle of an electromagnet used a filter, all three made of the coil with a convolution wire as many as 5000 a convolution and diameter of the nucleus of a coil $44.5 \mathrm{~mm}, 28.5$ $\mathbf{m m}$ and $17.5 \mathrm{~mm}$, a filter tested in a diesel engine. Testing done in the rpm the ignition is started 1100 until $1700 \mathrm{rpm}$, by opening throttle \% to $60 \%$ from $30 \%$. Testing first one was done by making constant round of $1500 \mathrm{rpm}$ and openings throttle vary from $30 \%$ to $60 \%$, next testing done with the variation of rpm start $1100 \mathrm{rpm}$ until $1700 \mathrm{rpm}$ by making constant valve as $40 \%$ and of $60 \%$. The purpose of the variations to obtain optimum result against consumption of material fuel ( $\mathrm{sfc}$ ) the most little uses. Testing was done in a laboratory material.
\end{abstract}

Keywords: specific fuel consumption, clustering, de-clustering, throttle

\begin{abstract}
ABSTRAK
Harga bahan bakar minyak terus naik, tetapi pasokan minyak berkurang. Kedua faktor tersebut yang mendorong peneliti untuk melakukan penelitian terkait efisiensi penggunaan bahan bakar. Telah dibuat tiga jenis bahan bakar minyak yang prinsipnya menggunakan filter electromagnet. Ketiganya terbuat dari koil dengan kawat konvolusi sebanyak 5.000, artinya, konvolusi dan diameter inti sebuah koil 44, mm, 28,5 mm dan 17,5 mm , filter diuji dalam mesin diesel. Pengujian dilakukan dalam putaran mesin mulai 1100 hingga $1700 \mathrm{rpm}$, dengan membuka throttle\% hingga 60\% dari $30 \%$. Pengujian pertama dilakukan dengan membuat putaran konstan 1500 rpm dan bukaan throttle bervariasi dari $30 \%$ hingga $60 \%$, pengujian selanjutnya dilakukan dengan variasi rpm mulai $1100 \mathrm{rpm}$ hingga $1700 \mathrm{rpm}$ dengan membuat valve konstan $40 \%$ dan $60 \%$. Tujuan variasi untuk mendapatkan hasil optimal terhadap konsumsi bahan bakar material (sfc) paling sedikit menggunakan. Pengujian dilakukan dalam bahan laboratorium.
\end{abstract}

Kata kunci: konsumsi bahan bakar spesifik, penganalisaan data, katup

pada tabung filter yang dialiri arus

\section{PENDAHULUAN}

Hadirnya inovasi alat penghemat bahan bakar dewasa ini yang mendominasi adalah pemanfaatan fungsi magnet permanen, atau biasa disebut besi sembrani. Kekuatan magnet akan terus menerus berkurang, seriring bertambahnya usia mesin pada kendaraan. Oleh karena itu, untuk menyempurnakan fungsi filter Bahan Bakar Minyak (BBM), maka diciptakan filter Bahan Bakar Minyak yang bekerja menggunakan prinsip pemanfaatan medan magnet listrik dari lilitan kawat listrik. Adapun arus listrik berasal dari sumber tegangan aki pada kendaraan motor. Kelebihan jenis filter, tergantung kekuatan magnet yang tetap berfungsi selama masih terdapat arus listrik. Pada penelitian tahap pertama, diameter inti kumparan dibuat tetap, sementara jumlah lilitan diameter kawat dan putaran mesin bervariasi. Filter dengan lilitan kawat tembaga berdiameter 0,15 $\mathrm{mm}$ pada putaran tinggi 5500 mengalami kenaikan Torsi sebesar $8,593 \%$, daya rata rata meningkat sebesar 10,682\% gas buang CO menurun sebesar 20,207\% serta 
pemakaian bakar spesifik (SFC) menurun sebesar 11,805\%.

Untuk meningkatkan hasil penelitian tahap pertama maka salah satunya adalah seperti yang dijelaskan dalam rumus Bio Savart yaitu membuat diameter inti kumparan bervariasi, ukuran diemeter inti kumparan menyebabkan medan magnet yang dihasilkan menjadi bertambah besar, sehingga molekul bahan bakar yang melewati medan magnet makin mudah bereaksi dengan oksigen sehingga terjadinya pembakaran sempurna semakin besar. Oleh karena itutujuan penelitian ini untuk mendapatkan model filter BBM yang paling maksimal dari berbagai variasi diameter inti kumparan yang digunakan yaitu $44,5 \mathrm{~mm}, 28,5$ $\mathrm{mm}$ dan 17,5 mm sedang jumlah lilitan konstan 5000 lilitan dengan diameter kawat 0,25 $\mathrm{mm}$ dan pengujian dilakukan pada kendaraan berbahan bakar solar. Data pengujian meliputi Torsi, Daya, SFC dan gas buang.

\section{METODE PENELITIAN}

Untuk melakukan penelitian ini, maka digunakan diagram alur seperti terlihat pada Gambar 1. Tahap pertama dilakukan studi pendahuluan yang meliputi studi literatur serta studi perbandingan untuk alat filter bahan bakar yang sudah ada. Langkah selanjutnya adalah melakukan perancangan alat serta pembuatan alat yang sudah dirancang.

Tahap berikutnya ialah menguji kinerja dari alat yang telah dibuat dengan variabel pengujian adalah diameter kawat kumparan elektromagnet 0,25 mm, jumlah lilitan elektromagnet 5000 lilitan, variasi putaran mesin 1300 RPM, 1500 RPM, 1700 RPM, dan 1900 RPM. Kemudian bukaan katup gas dibuat konstan 30\%, 50\% dan 60\%. Pengujian mesin diesel dilakukan dengan dosis konsumsi bahan bakar 30 cc untuk setiap putaran mesin. Sumber arus listrik untuk medan magnet diambil dari baterai dengan tegangan 12 volt.

Pengujian ini disesuaikan dengan setting yang telah ditetapkan dalam rig pengujian motor bakar diesel di laboratorium bahan bakar Jurusan Teknik Mesin, Fakultas Teknik, Universitas Indonesia, Depok. Penelitian menggunakan bahan bakar solar yang produksi Pertamina. Parameter yang konsumsi bahan bakar dan opasitas dihitung adalah daya mesin, efisiensi termal, (kehitaman gas buang).

\section{HASIL dan PEMBAHASAN}

Pengujian dilakukan dengan cara menguji mesin standar (tanpa memasang peralatan filter bahan bakar yang dirancang) dan dengan memasang filter bahan bakar pada saluran bahan bakar motor diesel, dengan variabel pengujian sesuai dengan yang telah ditetapkan di atas. Dari hasil pengujian dilakukan analisa untuk mendapatkan kesimpulan.

Spesifikasi alat:

\section{Diesel Engine Tester}

Type: Water cooled 4 cycle, diesel engine The No, of cylinder-bore $x$ stroke (piston displacement):4-83 x 100mm (2163 cc) Model: EWS.50

Max. absorbing shaft rotational speed (r.p.m.): $7000 \mathrm{rpm}$

Fuel consumption meter: Skewer type 3burette 30, 50, 100cc

Engine cylinder pressure $P-V$ diagram device Indicator diagram: Alternative cylinder pressure transducer, amplifier, trigger cathode-ray oscillo-scope.

Pada gambar 3. A menunjukan hubungan efisiensi bahan bakar yang disuplai ke mesin untuk dijadikan hasil daya Spesific Fuel Consumption (SFC) dengan berbagai variasi bukaan katup (throttle valve). Bukaan throttle valve semakin besar menandakan beban pada mesin yang juga besar. Hal 
berhubungan dengan seberapa banyak bahan bakar yang dapat mendorong daya pada mesin. Jika SFC rendah, berarti mengindikasikan pemakaian bahan bakar yang irit. Hal dapat dilihat SFC dengan menggunakan filter lebih besar dari pada yang tidak menggunakan alat dan perbedaanya cukup signifikan. Hal ini membuktikan pada bukaan throttle valve dalam penggunaan bahan bakarnya lebih banyak.

Pada beban sedang $50 \%$ dan beban tinggi dengan bukaan $60 \%$, penggunaan alat filter menunjukan nilai SFC yang tidak jauh berbeda. Hal ini menunjukan penggunaan alat tidak memberikan pengaruh yang signifikan terhadap daya laju aliran massa bahan bakar yang bisa menjadi daya output mesin. Grafik 4.B menunjukkan hubungan antara Spesific Fuel Consumption dengan variasi Putaran Mesin (RPM) pada bukaan Throttle Valve konstan 40 \%. Pada bukaan Throttle Valve konstan, semakin tinggi putaran mesin maka semakin besar beban pada mesin dan pemakaian bahan bakar juga semakin meningkat. Namun beban yang semakin besar mengakibatkan daya mesin yang berkurang. Hal ini berakibat specific fuel consumption semakin besar. Pada putaran-putaran rendah dan sedang penggunaan alat filter menunjukkan nilai-nilai SFC yang lebih rendah, hal ini menunjukkan penggunaan bahan bakar lebih irit tetapi perbedaanya tidak terlalu signifikan. Namun untuk putaran yang lebih tinggi yaitu di putaran 1700 RPM.

Penggunaan alat filter menunjukan nilai SFC yang jauh lebih rendah sesuai nilai data di atas. Dengan demikian, bahwa penggunaan alat filter pada putaran yang lebih tinggi memberikan pengaruh cukup signifikan dan dapat disimpulkan bahan bakar lebih irit.

\section{Hubungan antara FC dengan Throttle Valve (RPM 1500) dan FC dengan RPM}

Grafik 4. A menunjukkan hubungan antara konsumsi bahan bakar dengan bukaan throttle valve pada putaran mesin konstan yaitu 1500 RPM dengan atau tanpa tambahan alat. Pada bukaan throttle valve $30 \%$ hasil yang diperoleh adalah dengan penggunaan ketiga mesin dapat menghemat konsumsi bahan bakar walaupun perbedaannya tidak signifikan. Perbedaan terbesar ditunjukkan oleh alat 3 dengan perbedaan 0,128 $\mathrm{L} / \mathrm{Hr}$ (penghematan sebesar 6,9\%) dengan percobaan tanpa menggunakan alat. Pada bukaan throttle valve $40 \%$ dan $50 \%$ alat 1,2 maupun 3 juga tidak menunjukkan hasil yang signifikan pada konsumsi bahan bakar, walaupun alat 2 dan 3 tidak menunjukan hasil yang signifikan pada bukaan throttle valve $60 \%$, alat 1 menunjukkan nilai konsumsi bahan bakar yang paling kecil yaitu sebesar 2,512 L/Hr (penghematan sebesar dibandingkan tanpa menggunakan alat). Grafik 4. B menunjukkan hubungan antara konsumsi bahan bakar dengan kecepatan putaran mesin pada bukaan throttle valve konstan sebesar $40 \%$ dengan atau tanpa tambahan alat. Pada putaran 1100 RPM, 1300 RPM, dan 1500 RPM ketiga alat tidak menunjukkan perubahan yang signifikan pada konsumsi bahan bakar. Variasi nilai konsumsi bahan bakar didapatkan pada saat putaran mesin 1700 RPM. Alat 1 dan alat 2 menunjukkan hasil penghematan yang cukup signifikan. Alat 2 menyebabkan penghematan konsumsi bahan bakar sebesar 28\% dan alat 1 menghemat konsumsi bahan bakar sebesar 33\%.

\section{Hubungan antara BHP dengan Throttle Valve dan BHP dengan RPM (Throttle Valve 40)}

Berdasarkan pengujian yang dilakukan, didapatkan beberapa data, dan setelah dilakukan pengolahan, maka ditemukan hasil nilai Brake Horse Power dari mesin dengan tambahan alat 1 , alat 2, dan alat 3, maupun tanpa tambahan alat. 
Grafik 5. A menunjukkan pengujian pada 1500 RPM dengan bukaan throttle valve yang diubah dari $30 \%$ hingga $60 \%$. Nilai brake horsepower yang didapat dengan tambahan alat 1 pada bukaan throttle valve 30\% adalah 1,476 $\mathrm{HP}$, dengan alat 2 adalah 2,583 $\mathrm{HP}$, dengan alat 3 adalah 3,321 HP dan tanpa tambahan alat adalah 3,69 HP. Sedangkan untuk bukaan throttle valve $40 \%$ didapatkan nilai 12,548 HP untuk alat 1, untuk alat 2 sebesar 14,024 HP, untuk alat 3 sebesar 12,179 HP dan dengan tidak menggunakan alat tambahan didapatkan nilai 11,441 HP. Pada bukaan throttle valve 50\%, nilai BHP untuk alat 1 adalah 14,762 HP, untuk alat 2 adalah 15,5 HP, untuk alat 3 adalah 14,762 HP, sedangkan untuk yang tidak menggunakan alat adalah 13,286 HP. Untuk bukaan throttle valve paling besar yaitu 60\%, nilai bhp dengan menggunakan alat 1 adalah 8,119 HP, dengan alat 2 adalah 15,869 HP, dengan alat 3 adalah 15,869 HP, dan dengan tidak menggunakan alat adalah 15,5 HP. Dari hasil tersebut, dengan menggunakan alat 2 pada bukaan throttle valve $40 \%$ dan $50 \%$ terdapat kenaikan BHP sebesar 22,5\% dan $16,6 \%$. Jadi dari hasil pengujian itu dapat dilihat bahwa alat 2 memberikan kenaikan cukup signifikan pada daya mesin yang dihasilkan.

Untuk pengujian nilai BHP dengan putaran mesin yang diubah dari 1100 rpm hingga 1700 RPM pada bukaan throttle valve 40\% (Grafik 5. B), didapatkan nilai brake horsepower pada 1100 RPM dan dengan tambahan alat 1 pada adalah 11,367 HP, 11,637 HP dengan alat 2, 11,637 HP dengan alat 3, dan tanpa tambahan alat adalah 10,825 HP. Sedangkan untuk putaran mesin 1300 RPM didapatkan nilai 10,875 HP untuk alat 1, 12,474 HP untuk alat 2, 11,514 HP untuk alat 3, dan 11,514 HP dengan tidak menggunakan alat tambahan. Artinya, pada putaran mesin 1500 RPM, nilai bhp untuk alat 1 adalah 12,548 HP, untuk alat 2 adalah 13,655 HP, untuk alat 3 adalah 12,548 HP, sedangakan untuk yang tidak menggunakan alat adalah 12,917 HP. Untuk putaran mesin paling tinggi yaitu 1700 RPM, nilai bhp dengan menggunakan alat 1 adalah 8,365 HP, dengan alat 2 adalah 10,038 HP, dengan alat 3 adalah 10,038 HP, dan dengan tidak menggunakan alat adalah 10,038 HP. Dari hasil di atas, dengan menggunakan alat 2 pada putaran mesin 1300 RPM dan 1500 RPM, terdapat kenaikan BHP sebesar 8\% dan 5\%. Jadi, berdasarkan hasil pengujian di atas, dapat dilihat bahwa alat 2 memberikan kenaikan cukup signifikan pada daya mesin yang dihasilkan.

Setelah melakukan pengujian BHP, tahap selanjutnya dilakukan juga pengujian untuk mendapatkan efisiensi termal dari mesin diesel. Grafik 6.A menunjukkan pengujian pada 1500 RPM dengan bukaan throttle valve yang diubah dari 30\% hingga 60\%. Nilai efisiensi termal yang didapat dengan tambahan alat 1 pada bukaan throttle valve $30 \%$ adalah $2,060 \%$, dengan alat 2 sebesar 3,604\%, dengan alat 3 sebesar 4,634\%, dan tanpa tambahan alat adalah 5,149\%. Sedangkan untuk bukaan throttle valve $40 \%$ didapatkan nilai $17,506 \%$ untuk alat 1 , untuk alat 2 sebesar 19,565\%, untuk alat 3 sebesar 16,991\%, dan 15,961\% dengan tidak menggunakan alat tambahan. Pada bukaan throttle valve 50\%, nilai BHP untuk alat 1 adalah 20,595\%, untuk alat 2 adalah 21,625\%, untuk alat 3 adalah 20,595\%, sedangkan untuk yang tidak menggunakan alat adalah 18,536\%. Untuk bukaan throttle valve paling besar yaitu $60 \%$, nilai bhp dengan menggunakan alat 1 adalah 11,327\%, dengan alat 2 adalah 22,14\%, dengan alat 3 adalah 22,14\%, dan dengan tidak menggunakan alat adalah 21,625\%. Dari hasil di atas, dengan menggunakan 
alat 2 pada bukaan throttle valve $40 \%$ dan $50 \%$ terdapat kenaikan efisiensi termal yang cukup besar. Jadi dari hasil pengujian di atas dapat dilihat bahwa alat 2 memberikan kenaikan cukup signifikan pada efisiensi termal yang dihasilkan.

Berdasarkan grafik 6.B, terlihat bahwa penggunaan alat II pada sistem dapat membuat thermal efficiency yang didapatkan pada mesin menjadi lebih baik dan bahkan dibandingkan dengan penggunaan yang lain alat II adalah yang paling baik. Perbedaan thermal efficiency pada alat II dapat memberikan perbedaan lebih baik hingga $1 \%-2 \%$. Namun yang terlihat aneh adalah pada semua jenis pemakaian alat ketika kecepatan putaran dinaikkan menjadi 1700 RPM efisiensi thermalnya menurun.

\section{Hubungan Opasitas vs Throttle Valve (RPM 1500)}

Terlihat dengan pembebanan yang meningkat dari 30 menjadi 40 membuat opacity dari penggunaan alat yang berbeda tetap menurun, namun ketika pembebanan ditingkatkan lagi menjadi 50 yang terjadi pada penggunaan alat I adalah angka opacity naik. Kemudian ketika beban percobaan maksimum yaitu 60 diberikan, ternyata penggunaan alat baik dari I, II, maupun III justru membuat opacity meningkat walaupun ada yang naiknya hanya sedikit yaitu sekitar 10\% - 15\% tetapi ada juga yang naiknya cukup besar yaitu mencapai 200\%. Berkebalikan dengan ketika tanpa menggunakan alat apapun yang dimana seiring bertambahnya beban justru angka opacity kian menurun dari awal pembebanan 30 hingga mencapai 60 yaitu hanya 16,67\% saja. Dan yang dapat terlihat pada grafik adalah angka opacity paling buruk ketika beban maksimum didapatkan pada penggunaan alat III.

\section{KESIMPULAN}

Berdasarkan hasil pengujian dan analisa data yang diperoleh, maka dapat disimpulkan filter BBM terbaik adalah filter BBM 1, yaitu filter dengan berdiameter inti sebesar 2 dim pada putaran tinggi 1700 revolutions per minute (RPM) dan bukaan katup dibuat konstan sebesar $40 \%$ bisa menghemat bahan bakar sampai 33\%. Pengujian dilakukan dengan membuat putaran konstan sebesar 1500 RPM dan bukaan katup sebesar $60 \%$ alat yang terbaik juga pada filter 1 menghemat bahan bakar mencapai 36\%, sehingga dari beberapa pengujian menunjukkan semakin besar beban yang diberikan dan semakin besar putaran mesin maka terjadi perbedaan yang significant antara mesin standar dibandingkan dengan mesin diesel yang menggunakan filter.

\section{DAFTAR PUSTAKA}

[1] Andreas A, Yuwono, Yon, H. 2005. "Evaluation and Redesign Automotive Air Filters Base on Value Engineering and Quality Function Deployment (QFD)". The Product Design Symposium Atmajaya University. Yogyakarta

[2] Royer, D. L., R. A. Berner, dan J. Park. 2007. Climate Sensitivity Constrained by $\mathrm{CO}_{2}$ Concentration over the Past 420 Million Years. Nature. 446: 530 - 532

[3] Intergovernmental Panel on Climate Change. 2001. Radioactive Forcing of Climate Change, The Physical Science Basis: Contribution of Work Group I to the Third Asessment Report. IPCC. Cambridge and New York

[4] Nakicénovic, N., O. et al. 2000. IPCC Special Report on Emissions Scenario. Cambridge and New York: Cambridge University Press 
[5] Goode, P. R. et al. 2001. Earthshine Observations of the Earth's Reflectance. Geophysical Research Letter 28(9): 1671-1674

[6] Prasetyowati, A. 2008. Fenomena Pemanasan Global. Asia Pacific Forest Genetic Program. 12/30/2008. P: 2-3. ISBN:18582494

[7] Frochlich, C. 2006. Solar Irradiance Variability Since 1978. Space Science Reviews 00: 1- 13

[8] Chalid, Mochamad Nelson Saksono, Adiwar, dan Nono Darsono. 2005. Jurnal Makara, Studi Pengaruh Magnetisasi Sistem Dipol Terhadap Karakteristik Kerosin teknologi, Vol.8, No. 1, April 2005: 36-42

[9] Chaware, K. 2015. Review on Effect of Fuel Magnetism by Varying Intensity on Performance and Emission of Single Cylinder Four Stroke Diesel Engine. International Journal of Engineering Research. 3: 174-178

[10] Kumar, P. V., Patro, S. K., Pudi, V. 2014. Experimental study of a novel magnetic fuel ionization method in four stroke diesel engines. International Journal of Mechanical Engineering and Robotics Research. 3(1)

[11] Bosch. 1996. Automotive Handbook, Society of Automotive Engineer. O.ktober 1996. Edisi 4

[12] ISO 3929, 2003. Road VehicleMeasurement method for exhaust gas emissions during inspection or maintenance

[13] UN-ECE.1996. Regulasi No. 40, Uniform Provisions concerning to the approval of motorcycle equipped with a positive-ignition with regard to the emission of gaseous pollutant by the engine

[14] Nasir, Muhammad, Djarwanti, Cholid Syahroni, Moch Syarif Romadhon. 2004. Pengaruh penggunaan katalis terhadap lingkungan. Jurnal Teknologi, Edisi No.4 Tahun xviii, Desember 2004, 256-262

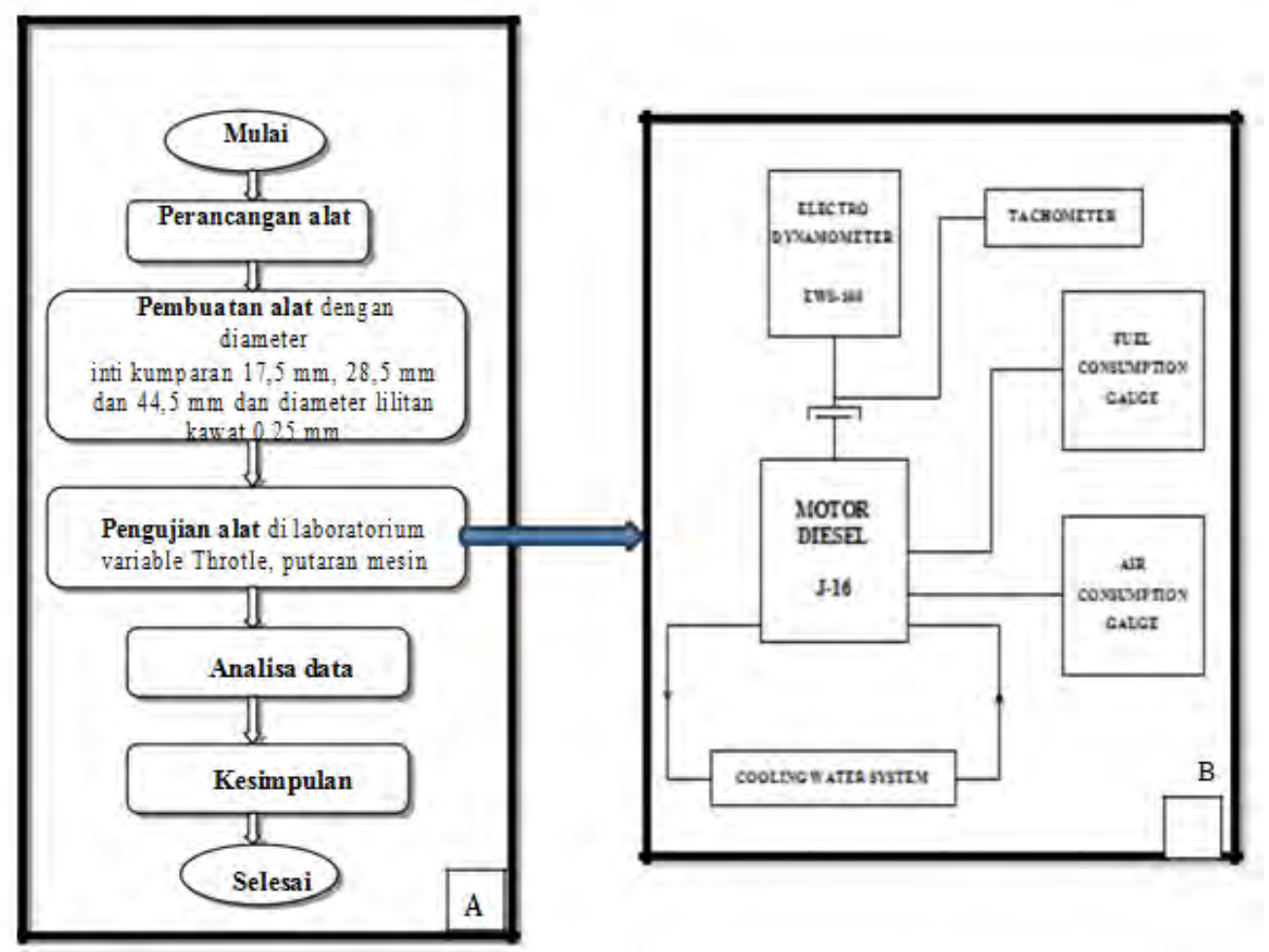

Gambar 1. A. Diagram metodologi penelitian, B. Diagram pengujian alat di Laboratorium bahan bakar di Fakultas Teknik Universitas Indonesia 

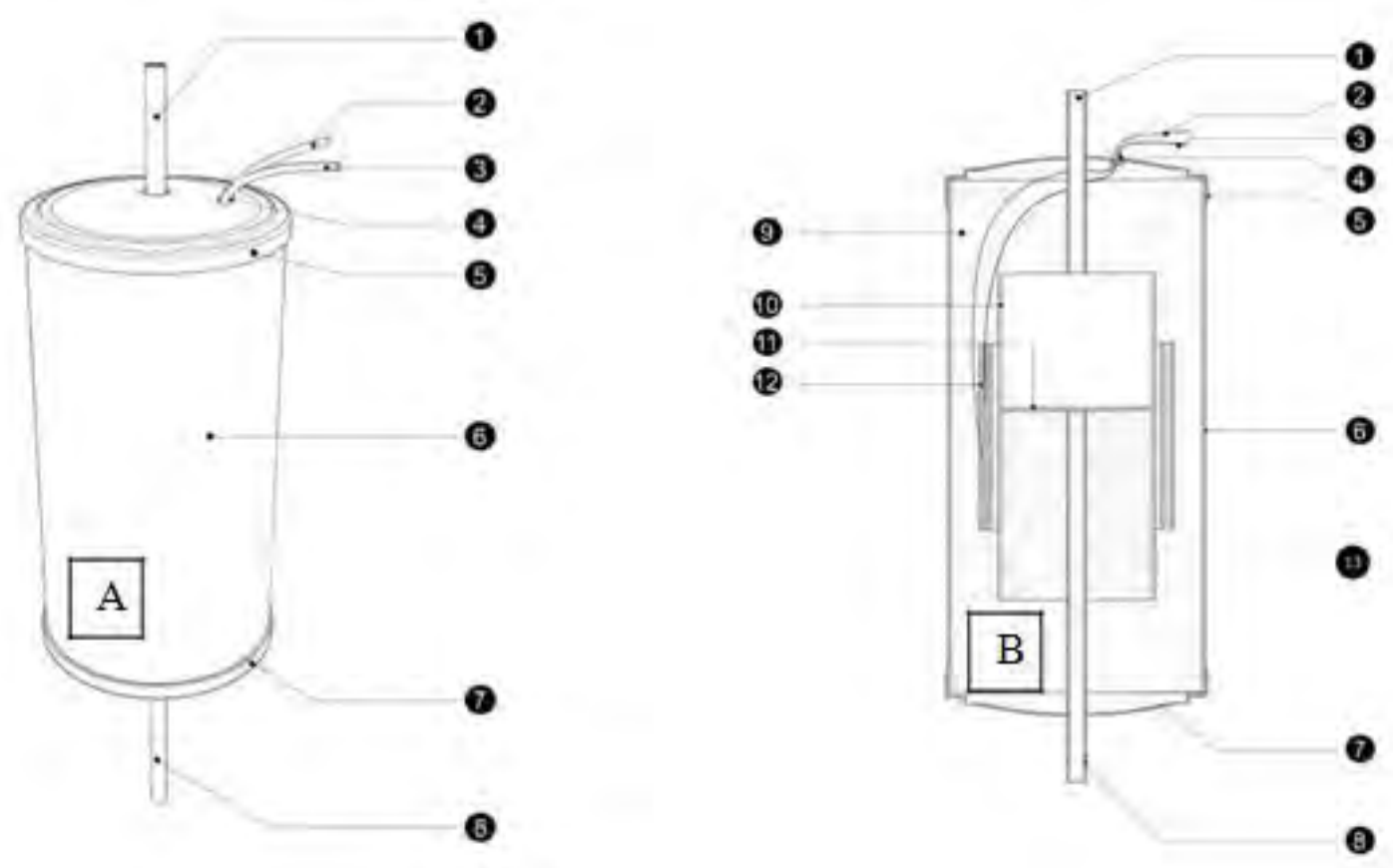

Gambar 2. A. Filter tampak bagian luar, B. Filter tampak bagian dalam

Keterangan gambar 2:

1. Pipa tempat keluarnya bahan bakar menuju mesin.

2. Kabel warna merah

3. Kabel warna hitam

4. Karet kabel

5. Tutup atas tabung stainless sebagai casing

6. Tabung stainless steel

7. Tutup bawah tabung stainless sebagai casing

8. Pipa tempat masuknya bahan bakar menuju filter BBM

9. Cairan resin

10. Tabung stainless steel

11. Kasa aluminium

12. Lilitan kawat email

13. serabut stainless steel 


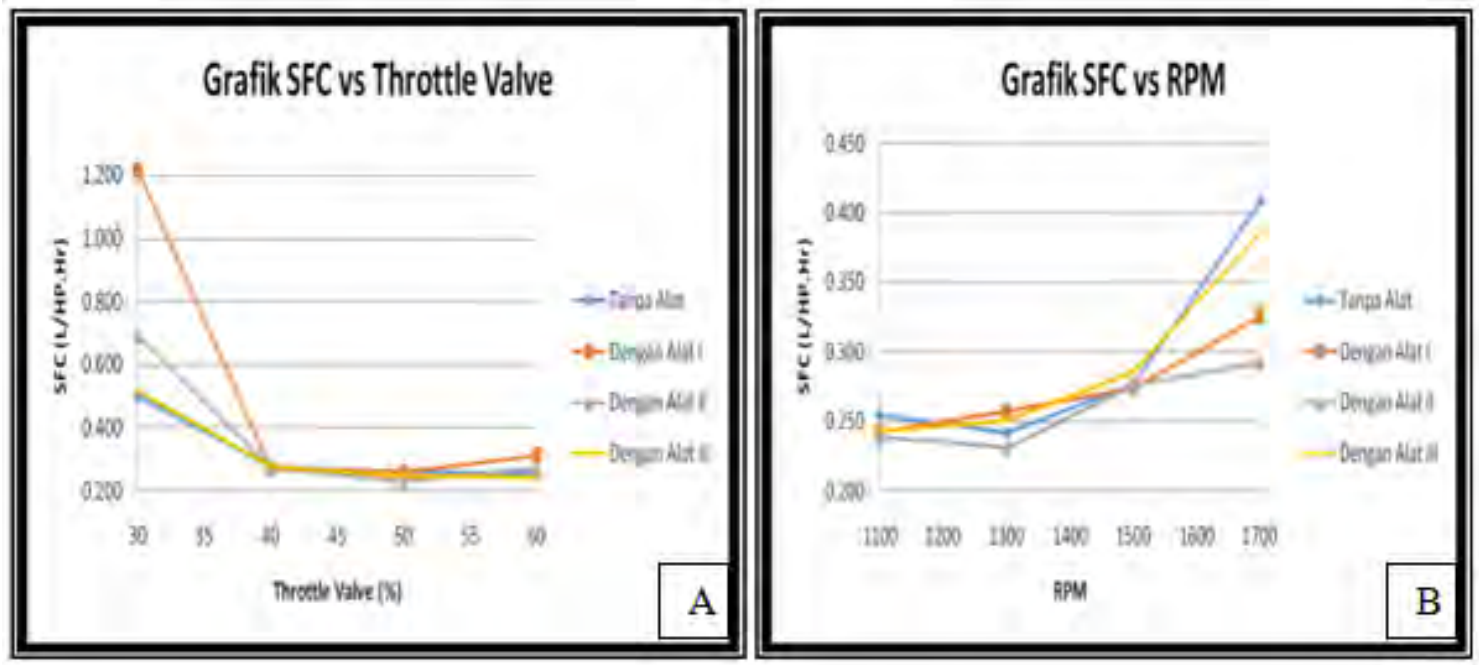

Gambar 3. A. Grafik Spesific Fuel Consumption SFC vs Throttle Valve (RPM 1500),

B. Grafik SFC vs RPM (Throttle Valve 40)
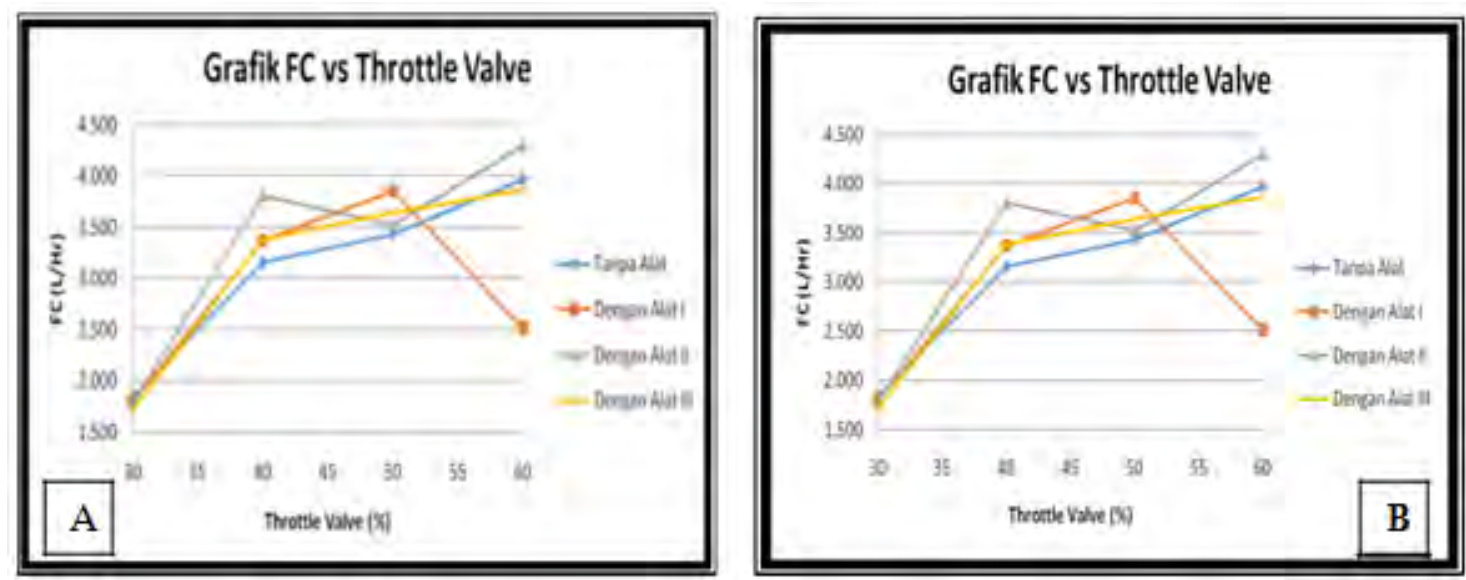

Gambar 4. A. Grafik FC vs Throttle Valve (RPM 1500),

B. Grafik FC vs RPM
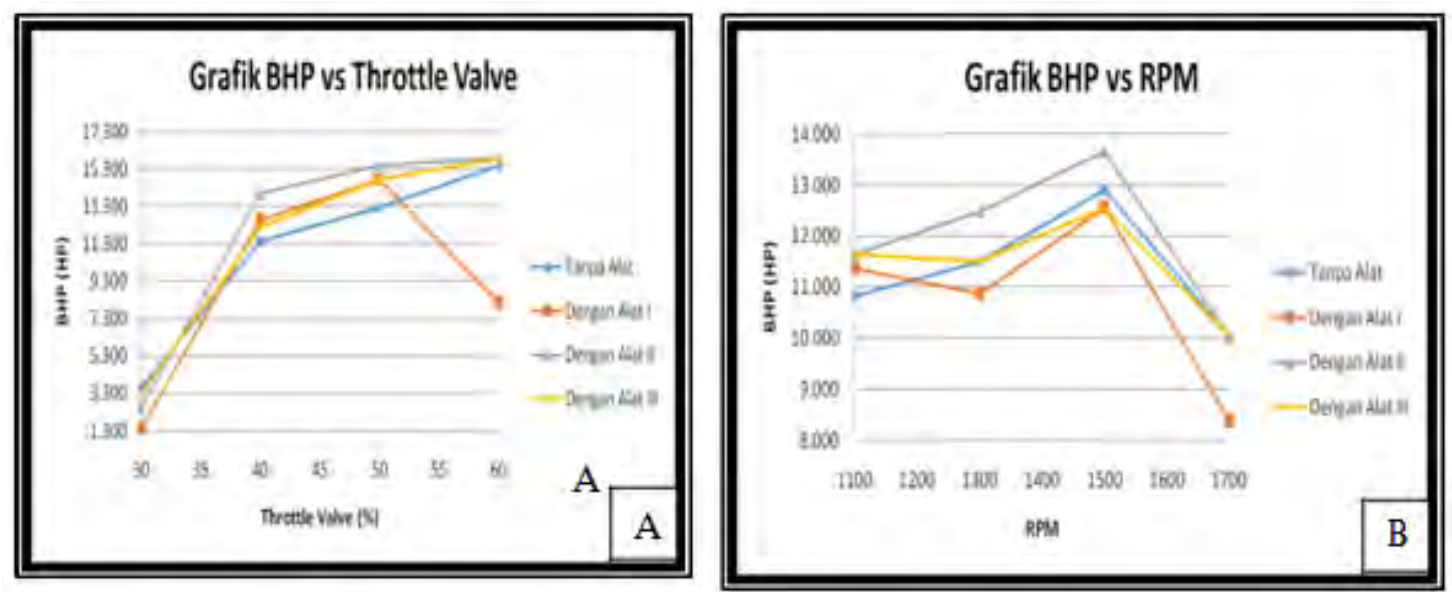

Gambar 5. A. Grafik BHP vs Throttle Valve (RPM 1500),

B. Grafik BHP vs RPM (Throttle Valve 40) 

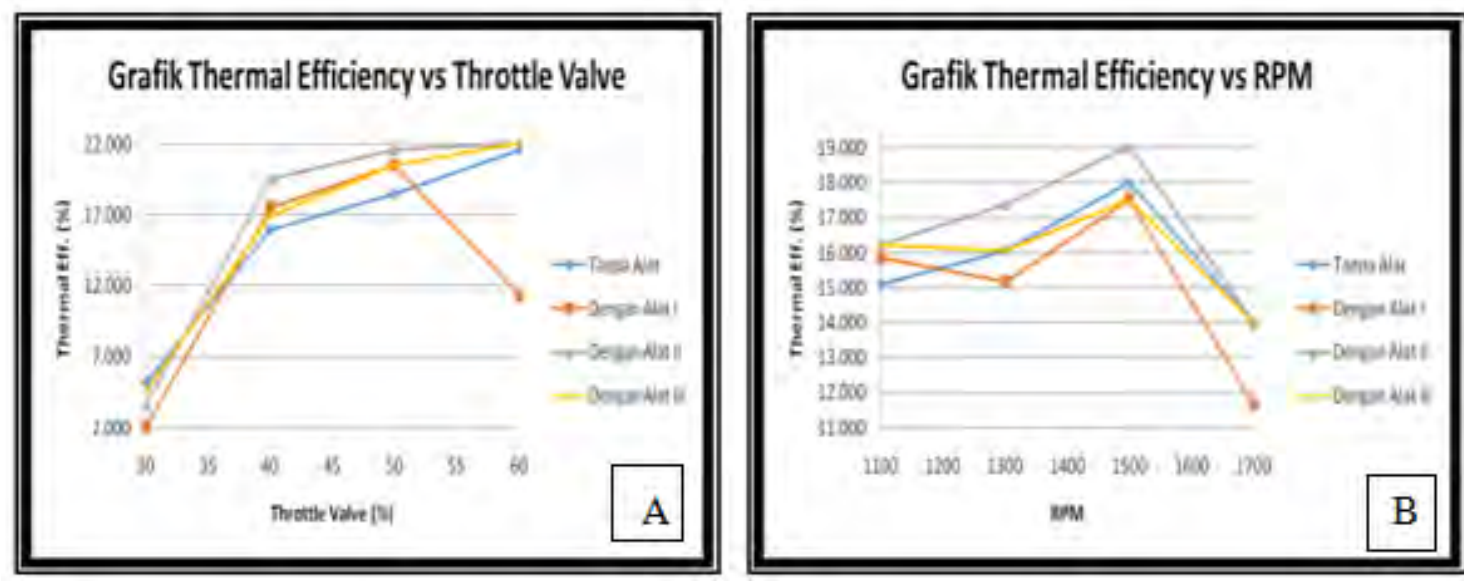

Gambar 6. A Grafik Efisiensi Thermal ( $\eta$ th) vs Throttle Valve (RPM 1500),

B. Grafik Efisiensi Thermal ( $\eta$ th) vs RPM (Throttle Valve 40)

Gambar 7. Grafik Opasitas vs Throttle Valve (RPM 1500) 
Tatun H Nufus dkk, Kajian Kualitas Pembakaran... 